\title{
TANGGUNG JAWAB NEGARA DALAM PENERAPAN HUKUM HUMANITER INTERNASIONAL STUDI KASUS KONFLIK BERSENJATA NON- INTERNASIONAL DI SURIAH DAN IMPLIKASINYA BAGI INDONESIA
}

\author{
Satria Nugraha \\ Alumni Magister Ilmu Hukum Pascasarjana Unisba \\ (Karyawan Prodi D3 Perhotelan UNTAG 1945 Cirebon) \\ e-mail : alter.cepe@gmail.com
}

\begin{abstract}
Abstrak-
Konflik bersenjata di Suriah berawal dari Demonstrasi anti-pemerintah di Daraa pada tanggal 23 Maret 2011 dan berkembang menjadi konflik bersenjata berkepanjangan antara pendukung rezim Bashar al-Asad dan kelompok oposisi. Konflik yang telah berlangsung tersebut telah memakan korban hingga 130.433 jiwa namun belum ada tanda-tanda akan segera berakhir ditandai dengan kegagalan perundingan antara kubu rezim dengan kelompok oposisi di jenewa pada awal tahun 2014. Konflik bersenjata non-internasional di Suriah juga berdampak bagi Indonesia. Di Suriah sendiri terdapat ribuan warga negara Indonesia yang belajar maupun bekerja sebagai Tenaga Kerja Indonesia juga dengan perkembangan terbaru dimana terdapat beberapa warga negara Indonesia yang bergabung dengan kelompok radikal ISIS yang merupakan salah satu oposisi di Suriah. Penelitian ini bertujuan untuk mengetahui dan memahami pertanggung jawaban para pelaku kejahatan perang dalam konflik Bersenjata Non-Internasional di Suriah berdasarkan Hukum Humaniter Internasional, dan Implikasi dari Konflik Bersenjata Non-Internasional terhadap Indonesia baik dampak yang terjadi secara langsung maupun tidak langsung. Penelitian yang digunakan yaitu melakukan pendekatan yuridis normatif yaitu pendekatan dengan mengkaji kaidah-kaidah hukum normatif atau melalui pendapat para pakar (doktrin) serta menggali asas-asas hukum yang terkait dengan asas-asas hukum yang berlaku dalam konflik bersenjata non-internasional, dengan data sekunder yang diperoleh dari studi kepustakaan dan dianalisis dengan menggunakan metode normative kualitatif. Hasil penelitian ini menunjukkan bahwa Hukum Humaniter Internasional para pelaku kejahatan perang dalam konflik bersenjata non-internasional di Suriah dapat dimintai pertanggung jawaban dan diadili atas kejahatannya. Bahwa konflik bersenjata non-Internasional di Suriah memiliki dampak bagi Indonesia baik secara langsung maupun tidak langsung.
\end{abstract}

\section{Kata Kunci : Konflik Bersenjata non-Internasional, Suriah, Hukum Humaniter Internasional}

Abstract- The armed conflict in Syria began with an anti-government demonstration in Daraa on March 23, 2011, and developed into a prolonged armed conflict between supporters of the Bashar alAsad regime and opposition groups. The ongoing conflict has caused 130,433 deaths, but there are no signs that it will end soon due to the failure of negotiations between the regime and opposition groups in Geneva in early 2014. The non-international armed conflict in Syria also affected Indonesia. In Syria itself, there are thousands of Indonesian citizens who study and work as Indonesian Workers with the latest developments where there are several Indonesian citizens joining the radical ISIS group which is one of the oppositions in Syria. This study aimed at determining and understanding the responsibility of perpetrators of war crimes in non-international armed conflict in Syria based on International Humanitarian Law and the implications of non-international armed conflicts in Indonesia both direct and indirect impacts. This study used normative juridical approach by examining normative legal norms or through the opinions of experts (doctrine) and exploring legal principles related to applicable legal principles in non-international armed conflicts, with secondary data obtained from literature study and analyzed using qualitative normative method. The result indicates that according to International Humanitarian Law, perpetrators of war crimes in noninternational armed conflict in Syria can be held accountable and tried for their crimes since noninternational armed conflict in Syria has some impacts on Indonesia both directly and indirectly.

Key Word: Non-International Armed Conflict, Syria, International Humanitarian Law 
Satria Nugraha, Tanggung Jawab Negara Dalam Penerapan Hukum Humaniter Internasional Studi Kasus...

\section{A. PENDAHULUAN}

Hukum tentang tanggung jawab Negara atau yang disebut dengan jurisdiksi Negara adalah hukum yang mengatur kekuasaan Negara untuk melakukan suatu tindakan. Hukum tentang tanggung jawab Negara itu sendari berarti hukum mengenai kewajiban Negara yang timbul ketika Negara telah atau tidak melakukan suatu tindakan. Rossalyn Higgins menggunakan istilah accountability disamping responsibility yang berarti terdapat liability untuk tindakan Negara yang melanggar hukum internasional dan harus dilaksanakan. Negara memiliki keinginan untuk melaksanakan perbuatan atau mental capacity perbuatannya. (Higgins, Rosalyn, Oxford University Press,UK.)

Dixon memberikan pengertian "State Responsibility" kedalam dua pengertian:

a. untuk menunjukkan aturanaturan prosedural yang berlaku dalam pembentukan tanggung jawab atas pelanggaran terhadap setiap kewajiban internasional apapun.

b. untuk menunjukkan aturan prosedural dan substantif yang berkaitan dengan kasus tertentu yang mengakibatkan tanggung jawab terhadap pelanggaran hak warga negara asing.Lahirnya Tanggung Jawab

Dalam tulisan ini penulis akan mengangkat peran tanggung jawab Negara dalam Konflik di Suriah yang berlangsung sejak Maret 2011 lalu dan telah menelan korban lebih dari 100.000 jiwa dan membuat ribuan warga Suriah mengungsi ke negara lain untuk menyelamatkan diri. Konflik antara pemerintah dengan kelompok oposisi yang merupakan rakyatnya sendiri tersebut telah banyak mendapat respon dari masyarakat internasional karena sikap pemerintah Suriah yang menggunakan kekerasan untuk menyerang rakyatnya sendiri. ${ }^{1}$ Dalam konflik bersenjata internal yang terjadi, pihak pemerintah ternyata melancarkan serangan terhadap penduduk sipil yang tidak ikut ambil bagian langsung dalam peperangan, sebagaimana yang terjadi di Houla pada tanggal 25 Mei 2012. (Joshua Landis, Free Syrian Army Founded by Seven Officers to Fight the Syrian Army, 2011) Hal ini tentu bertentangan dengan prinsip pembedaan (distinction principle) yang dikenal di dalam hukum 
Satria Nugraha, Tanggung Jawab Negara Dalam Penerapan Hukum Humaniter Internasional Studi Kasus...

humaniter. ${ }^{2}(\mathrm{KGPH} \quad$ Haryomataram, Pengantar Hukum Humaniter 2007)

Konflik bersenjata yang terjadi di Suriah merupakan konflik bersenjata non international.Dalam Hukum Humaniter Internasional, suatu konflik bersenjata digolongkan menjadi dua macam yaitu konflik bersenjata internasional (International Armed Conflict) dan konflik bersenjata non internasional (Non-International Armed Conflict). Konflik bersenjata internasional adalah konflik bersenjata yang terjadi antar negara dan CAR Conflict (Colonial Domination, Alien Occupation, dan Racist Regimes). (Arlina Permanasari, Aji Wibowo, Pengantar Hukum Humaniter. 2003).

$$
\text { Konflik bersenjata non- }
$$
internasional adalah konflik bersenjata yang terjadi dalam wilayah suatu negara antara kelompok bersenjata yang bukan merupakan bagian dari angkatan bersenjata negara tersebut bertikai dengan pemerintah pusat negara itu. Selain itu juga Konflik bersenjata non internasional dapat terjadi karena adanya pertikaian antara faksi-faksi di suatu Negara. Dengan adanya penggolongan macam-macam konflik tersebut maka Konflik bersenjata yang terjadi di Suriah merupakan konflik bersenjata non internasional, karena Konflik bersenjata internal di Suriah tersebut melibatkan antara pemerintah Suriah dengan para pemberontak yang menamakan kelompok organisasinya dengan nama Tentara Pembebasan Suriah atau Free Syrian Army (FSA).

International Committee of the Red Cross (ICRC), secara resmi menyatakan bahwa konflik berdarah yang terjadi di Suriah merupakan perang saudara. Status yang diumumkan Palang Merah Internasional pada hari Minggu tanggal 15 juli 2012 tersebut, memberi implikasi akan adanya tuntutan kejahatan perang pada pihak-pihak yang terlibat di dalamnya. Pernyataan ICRC muncul ketika tim pemantau PBB mengumpulkan detail baru tentang apa yang terjadi di Desa Treimseh yang disebut kelompok oposisi sebagai pembantaian oleh tentara rezim Presiden Bashar al-Assad.

Prinsip prinsip mengenai tanggung jawab Negara telah dirumuskan dalam the international law commission: article of state responsibility yang diedarkan oleh Majelis Umum PBB. 
Satria Nugraha, Tanggung Jawab Negara Dalam Penerapan Hukum Humaniter Internasional Studi Kasus...

Dalam kasus ini Pemerintah Suriah yang dipimpin oleh Bashar Al-Assa memiliki tanggung jawab dalam melindungi warga sipil yang menjadi korban serangan pemerintah dalam konflik bersenjata non internasional di Suriah (Secretary General Report of CW Investigation). Selain dari Article of State Responsibility, terdapat suatu instrument hukum internasional yang khusus mengatur mengenai pertanggung jawaban atas tindak pidana internasional, yaitu statute roma tahun 1999 yang melahirkan Mahkamah Pidana International (ICC). Kedua instrument hukum internasional tersebut telah menjadi bagian dari hukum kebiasaan internasional karena pengaturaanya telah diterima oleh seluruh masyarakat internasional

Penggunaan senjata kimia dalam konflik bersenjata non internasional di Suriah termasuk salah satu bentuk kejahatan perang karena telah jelas melanggar Hak Asasi Manusia serta dapat menyebabkan kerusakan atau kerugian yang tidak perlu dan tidak seharusnya terjadi di dalam konflik bersenjata internasional maupun internal. Suatu negara yang melakukan suatu tindakan yang sah dapat diminta tanggung jawabnya apabila merugikan negara lainnya.

Para pihak dan Individu dari yang terlibat dalam konflik bersenjata noninternasional di Suriah telah melakukan pelanggaran serius terhadap hak asasi manusia internasional dan hukum humaniter pada skala yang luas. Human Rights Watch telah menyimpulkan atas dasar penyelidikan bahwa pemerintah dan pro-pemerintah pasukan telah bertanggung jawab melakukan kejahatan terhadap kemanusiaan dan kejahatan perang. Pemerintah terus melakukan serangan udara dan artileri membabi buta terhadap daerah pemukiman dan sewenang-wenang menahan, menyiksa, dan ekstra-yudisial mengeksekusi warga sipil dan kombatan. (Human Rights Watch Reports, Torture Archipelago)Pada bulan Agustus, serangan senjata kimia menewaskan ratusan warga sipil, termasuk anak-anak, dekat Damaskus. Sebuah penyelidikan PBB menetapkan bahwa agen saraf Sarin digunakan. Sementara pemerintah menyangkal bertanggung jawab, bukti yang ada sangat menunjukkan bahwa pasukannya bertanggung jawab atas serangan. 
Satria Nugraha, Tanggung Jawab Negara Dalam Penerapan Hukum Humaniter Internasional Studi Kasus...

Suriah telah melanggar secara radikal dari banyak kewajiban HAM-nya; dengan demikian, negara lain yang turut meratifikasi perjanjian-perjanjian bisa menjalankan proses terhadap Suriah sebelum ICJ tersebut. Ini masih harus dilihat jika ada negara akan bersedia untuk mengambil sikap seperti itu untuk menantang tindakan rezim Assad dalam menuntut perang.

Mengenai penerapan Non-State Actor Responsibility for Internationally Wrongful Acts terhadap individu-individu dari berbagai kelompok yang bertikai di Suriah. Terdapat beberapa kemungkinan, Dalam banyak situasi, aktor non-negara dan negara dapat secara terpisah berkontribusi, atau memperburuk, hasil berbahaya tunggal. Misalnya, negara dapat memberikan dukungan kepada aktor non-negara, atau aktor non-negara dapat memberikan dukungan untuk (bantuan / membantu) negara, melanggar hukum internasional, dengan individu tersebut kemudian melakukan internasional wrongfull acts (misalnya, pelanggaran hukum internasional kemanusiaan atau hukum hak asasi manusia, atau aksi teroris) atau sebaliknya menyebabkan kerusakan. (ICJ
Report on Military and Paramilitary Activites in and against Nicaragua) tindakan yang terpisah tersebut juga dapat terjadi ketika negara gagal untuk mengambil langkah-langkah yang cukup untuk mencegah aktivitas berbahaya aktor non-negara, misalnya, ketika mereka membiarkan kehadiran teroris di territory mereka. (Trapp KN (2015) Shared responsibility and non-state terrorist actors. Neth Int Law Rev.) contoh lain muncul ketika negara gagal untuk memanggil aktor non-negara untuk menjelaskan tindakan salah yang dilakukan atau luka yang disebabkan (misalnya, dengan tidak hidup sampai tugas mereka untuk menuntut atau mengekstradisi (Nollkaemper PA, Jacobs D (2013) Shared responsibility in international law: a conceptual framework. Mich J Int Law 34). dalam situasi tersebut, tanggung jawab aktor non-negara dan negara dapat terlibat atas dasar perilaku diskrit. Hal ini sejalan dengan beberapa paradigma klasik hukum tanggung jawab internasional, yang cenderung mengisolasi tindakan aktor yang berbeda dengan maksud untuk menahan mereka untuk memperhitungkan secara independen satu sama lain. 
Satria Nugraha, Tanggung Jawab Negara Dalam Penerapan Hukum Humaniter Internasional Studi Kasus...

Dalam situasi lain, mungkin tepat untuk mengadopsi perspektif aksi bersama, di mana kontribusi berbagai aktor 'mungkin tidak terisolasi satu sama lain. Bisa saja satu kelompok oposisi bersenjata melakukan operasi militer gabungan bersama-sama dengan negara terhadap negara lain yang melanggar prinsip non-intervensi, dan / atau menyebabkan korban sipil yang melanggar aturan hukum seperti yang dilakukan oleh Pasukan Udara Amerika yang melakukan operasi militer bersama dengan Pejuang Suku Kurdi, atau kerjasama antara Militer Suriah dan Militer Rusia dalam melakukan operasi Militer pada konflik bersenjata noninternasional di Suriah. Dalam situasi ini, mungkin ada perilaku tunggal yang dilakukan oleh beberapa pelaku, mengakibatkan cedera tunggal, misalnya Penyerangan kota Allepo baru baru ini oleh pasukan koalisi untuk melepaskan kota dari blokade Pasukan ISIS (Bílková $V$ (2015) Armed opposition groups and shared responsibility. Neth Int Law Rev. do). Hal ini dapat disampaikan bahwa perilaku ini harus secara teknis dikaitkan dengan lebih dari satu pelaku (yaitu, dua atau beberapa atribusi), meskipun beberapa atribusi tersebut agak jarang dalam hukum internasional, juga dalam konteks tanggung jawab Negara.

Contoh nyata terkait Tanggung Jawab Negara dalam konflik bersenjata noninternasional di Suriah adalah operasi militer yang dilakukan bersama-sama oleh pasukan negara dan perusahaan militer swasta atau sekut, yang mengakibatkan pelanggaran hukum humaniter seperti yang baru baru ini terjadi di Aleppo. contoh yang terakhir adalah sebuah perusahaan multinasional yang memberikan dukungan logistik untuk kelompok oposisi . bekerja sama dengan satu sama lain walaupun secara singkat, negara dan aktor non-negara juga dapat mengambil tindakan bersamaan meskipun belum terkoordinasi berkontribusi terhadap tindakan yang sama. Hal ini dapat terjadi di mana organisasi negara atau internasional pasif ketika kelompok bersenjata melakukan kekejaman atau meluncurkan serangan teroris, atau di mana negara gagal untuk menuntut atau mengekstradisi teroris dugaan hadir di wilayahnya. Dalam semua kasus ini, bersama (gabungan / bersamaan / kumulatif) tanggung jawab negara atas negara maupun aktor non 
Satria Nugraha, Tanggung Jawab Negara Dalam Penerapan Hukum Humaniter Internasional Studi Kasus...

negara terhadap pelanggaran hukum internasional.

\section{B. PEMBAHASAN}

1. Tanggung Jawab Negara dalam konflik bersenjata noninternasional di Suriah

Negara bertanggung jawab dalam hukum internasional untuk perbuatan atau tindakan yang bertentangan dengan kewajiban internasional negara itu. Komisi Hukum Internasional (International Law Commission) telah membahas persoalan tanggung jawab negara ini sejak tahun 1956 namun baru pada tahun 2001 berhasil merumuskan rancangan Pasal-pasal tentang Tanggung Jawab Negara karena Perbuatan yang Dipersalahkan menurut Hukum Internasional (draft Articles on Responsibility of States for Internationally Wrongful Acts, selanjutnya dalam tulisan ini disebut "Artikel") yang kemudian diedarkan oleh Majelis Umum PBB. Dalam Resolusi A/RES/ 59/35 (2004) Majelis Umum mengundang negara-negara anggota $\mathrm{PBB}$ untuk memberi tanggapan tentang langkah selanjutnya dan memutuskan untuk mempertimbangkan masalah itu kembali pada tahun 2007 .

Hukum internasional tentang tanggung jawab negara adalah hukum internasional yang bersumber pada hukum kebiasaan internasional. Komisi Hukum Internasional berkembang melalui praktik negara-negara dan putusanputusan pengadilan internasional. Pengadilanpengadilan internasional bahkan telah sejak lama mengutip dan menyetujui rancangan Artikel yang dibuat oleh Komisi Hukum Internasional, sehingga kalaupun rancangan Artikel itu tidak menjelma sebagai konvensi, dapat dipastikan bahwa ia akan tetap berpengaruh besar pada pengadilan-pengadilan internasional itu. Oleh karena itu, sesuai dengan ketentuan Pasal 38 Ayat (1) Statuta Mahkamah Internasional 
(International Court of Justice), praktik demikian akan semakin memperkuat kedudukan hukum kebiasaan internasional (yang mengatur tentang pertanggungjawaban negara) sebagai sumber primer hukum internasiona 1.

Timbulnya tanggung jawab negara dalam hukum internasional adalah bahwa tidak ada satu negarapun yang dapat menikmati hak-haknya tanpa menghormati hak-hak negara lain. Oleh sebab itu, setiap pelanggaran terhadap hak negara lain menyebabkan suatu negara wajib untuk memperbaiki atau bertanggunggungjawab negara umumnya diartikan sebagai kewajiban untuk melakukan pemulihan kerugian (duty to make reparation), yang timbul dari akibat adanya tindakan (act or ommission) yang dapat dipersalahkan (wrongful act), karena langgar kewajiban internasional.

Dalam Tanggung Jawab Negara ada ukuran untuk menentukan kegiatan-kegiatan yang digolongkan sebagai abnormally dangerous (the standard of abnormality) didasarkan pada pertimbangan sebagai berikut :

a. Tingkat risiko (the degree of risk). Risiko dianggap tinggi apabila tidak dapat dijangkau oleh upaya yang lazim atau menurut kemampuan teknologi yang telah ada

b. Tingkat bahaya (the gravity of harm) sulit untuk dicegah pada saat mulai terjadinya.

c. Tingkat kelayakan upaya pencegahan (the appropriateness), sudah dilakukan upaya pencegahan secara maksimal; Pertimbangan terhadap keseluruhan nilai kegiatannya (value of activity) telah dilakukan secara memadai.

Nilai atau manfaat kegiatan tersebut bagi masyarakat (the value of activity to the community) Artikel menentukan bahwa setiap tindakan atau perbuatan suatu negara yang dipersalahkan 
secara internasional melahirkan pertanggungjawaban

internasional negara yang bersangkutan. Perbuatan tersebut dikatakan salah hanya jika:

a. berdasarkan hukum internasional ia dapat diterapkan kepada negara itu, dan

b. melahirkan suatu pelanggaran terhadap suatu kewajiban internasional.

\section{Implikasi Konflik Non-} Internasional di Suriah bagi

\section{Indonesia}

Dampak konflik bersenjata noninternasional di Suriah secara langung berdampak pada WNI yang berada di negara tersebut. Sejak terjadi konflik di Suriah, Maret 2011, pemerintah melalui Kementerian Luar Negeri membentuk tim penanganan penyelamatan TKI/WNI yang diberangkatkan langsung ke negara tersebut. Sementara itu, KBRI di Suriah hingga kini masih menempatkan petugas di sekitar wilayah utama konflik, yakni Homs, Hama, dan Daraa, untuk mengevakuasi TKI/WNI. Terkait upaya pemulangan jika di negara Suriah mengalami larangan terbang, evakuasi TKI/WNI akan dilakukan melalui jalur darat ke Lebanon dan Jordania, lalu melalui jalur udara menuju Indonesia. Berdasarkan data Pusat Penelitian dan Pengembangan Informasi BNP2TKI, total TKI di Suriah adalah 11.760 orang. Sebagian besar (11.559 orang) merupakan TKI penata laksana rumah tangga.

Perkembangan perang Suriah saat ini kian melebar.Pelemparan senjata kimia oleh pemerintah Suriah di Ibu Kota Damaskus telah memicu serangan militer AS terhadap Suriah. Hal ini tentunya akan menyebabkan konflik global. Secara tidak langsung Indonesia pun akan turut terkena dampak buruknya. 1. Kenaikan harga minyak dunia Suriah, sebagai salah satu negara pengekspor minyak dari 
Timur Tengah, sebenarnya hanya memiliki sedikit minyak yang diekspor. Namun, jika Amerika melakukan penyerangan terhadap Suriah, maka kestabilan Timur Tengah akan terganggu sehingga menyebabkan suplai minyak juga terganggu. Hal ini tentunya akan menaikkan kekhawatiran pasar, sehingga mengangkat harga minyak. Indonesia sebagai negara pengimpor minyak tentunya akan terimbas dampaknya. Harga minyak dunia yang naik akan berdampak pada anggaran susidi bahan bakar minyak (BBM) domestik. Dalam keadaan seperti ini kenaikan harga BBM mungkin bisa terjadi lagi. Namun, dengan kondisi inflasi saat ini yang cukup tinggi, menaikan harga BBM justru akan memperburuk perekonomian. Alternatif lain kini sedang diupayakan pemerintah untuk mencegah terjadinya kenaikan BBM jika harga minyak dunia makin melambung tinggi.
2. Pelemahan nilai rupiah Dampak perang Suriah terhadap pelemahan nilai rupiah ini masih berhubungan dengan harga minyak dunia. Kenaikan harga minyak dunia akan memberikan kontribusi yang cukup besar terhadap meningkatnya permintaan valuta asing sebagai negara pengimpor minyak. Kondisi ini menyebabkan nilai rupiah melemah terhadap US\$. Dampak negatif dari penurunan nilai rupiah tersebut akan meningkatkan biaya impor bahan baku dan mendorong terjadinya inflasi.

Dampak tidak langsung yang paling berbahaya bagi Indonesia adalah paham radikalisme yang disebarkan oleh ISIS yang merupakan salah satu kelompok oposisi pada konflik bersenjata non-internasional

Suriah.Dukungan untuk Negara Islam (IS, sebelumnya dikenal sebagai ISIS) di Indonesia meningkatkan risiko kekerasan meskipun kapasitas kelompokkelompok ekstremis kekerasan 
masih rendah. Ini bisa berubahdengan kembalinya prajurit ISasal Indonesia yang sekarang berperang di Suriah dan Irak yang akan memilikipelatihan, pengalaman tempur, dan potensi kepemimpinan sebagai bagian dari kelompok ekstrimis dimasyarakat Indonesia.

Pada 22 September 2014 juru bicara IS Al-Adnani memberikan nasihat untuk membunuh orang asing terkait dengan koalisi pimpinan AS juga bisa memberikan insentif kepada para pendukung ISIS Indonesia menargetkanBarat sebagai cara mendapatkan persetujuan dari pemimpin khalifah di Indonesia .kutipan pernyataanya sebagai berikut:

"Jika Anda tidak memiliki bom atau peluru, dan kafir (kafir) dari Amerika atau Perancis atau salah sekutu mereka terlihat, serang di kepala dengan batu, serang dia dengan pisau, serang dengan mobil Anda, membuang dia dari gedung tinggi atau meracuninya!”.
Calon teroris di Indonesia selama empat tahun terakhir telah berfokus pada target domestik, sebagian besar polisi, dan mereka terus melakukannya setelah Instruksi dari AlAdnani, bagaimanapun, bisa dianggap serius oleh mereka yang berjanji setia kepada IS dan sudah mencoba untuk menggunakan

kekerasan.Sekelompok kecil orang Indonesia terinspirasi oleh Bakri dan Choudary menjadi mesin dari jaringan pro-ISIS di Indonesia.Kelompok ini menjalankan www.almustaqbal.net website, menyebut diri sebagai AlMustaqbal.mereka memiliki link ke sebagian besar kelompok teroris masih beroperasi di Indonesia,termasuk Mujahidin dari Indonesia Timur danMujahidin Indonesia Barat. Kelompok ini pada 29 Juni 2014 mengumumkan pembentukan kekhalifahan.Dan pejuang di Suriah, termasuk 


\begin{tabular}{|c|c|}
\hline $\begin{array}{l}\text { Bahrum Syah, } \quad \text { telah } \\
\text { membentukunit } \quad \text { Indonesia- }\end{array}$ & $\begin{array}{l}\text { Irak pada bulan Juni } \\
\text { yangmemberi }\end{array}$ \\
\hline Malaysia dari ISIS di Suriah & pemenang; \\
\hline yang kabarnya bertujuan & konsep kekhalifahan; dan ISIS \\
\hline akhirnya mendirikankepulauan & menggunakan media \\
\hline Negara Islam di Asia Tenggara, & yangcanggih. \\
\hline yang disebut Daulah Islamiyah & Pada saat yang sama, ISIS telah \\
\hline Nusantara. & memicu reaksi lebih besar dari \\
\hline Munculnya ISIS mungkin & yang pernah terlihat sebelumnya \\
\hline contoh langka & Indonesia \\
\hline perkembangan & menunjukkan \\
\hline internasional di negara lain & dukungan \\
\hline menjadi motor & padapikiran-pikiran \\
\hline perekrutan jihad di Indonesia.Di & radikal.Orang yang terlibat \\
\hline masa lalu, semangat jihad & tetap berbahaya, dan itu adalah \\
\hline bersifat lokal. Ketika Indonesia & penyebab keprihatinan bahwa \\
\hline pergi ke Afghanistan untuk & narapidana \\
\hline melatih di pertengahan 1980 -an & keamanan tinggi terus menjadi \\
\hline dan awal 1990-an,mereka & salah satu dai yang paling aktif \\
\hline didorong oleh represi $\mathrm{d}$ & mencari pandangan ISIS \\
\hline lan keinginan untuk & ajarannya. \\
\hline
\end{tabular}
mengembangkan kapasitas untuk melawan Soeharto.

\section{PENUTUP}

Kampanye pengeboman Jemaah Islamiyah antara tahun 1999 dan 2002 dipicu oleh komunal konflik di rumah, di Ambon dan Poso.. Daya tarik ISIS berbeda, kombinasi nubuat agama yang melibatkan Sham (lebih besar Suriah); string kemenangan di

\section{Simpulan}

Berdasarkan uraian permasalahan yang telah dibahas pada pemaparan pada bab sebelumnya maka telah dicapai suatu kesimpulan dari penelitian ini yaitu: 
a. Tanggung Jawab Negara dalam Konflik Bersenjata non Internasional di Suriah berdasarkan penelitian penulis berpendapat bahwa para pihak yang terlibat baik pemerintah Suriah maupun kelompokkelompok Oposisi yang terlibat dalam konflik bersenjata non Internasional di Suriah dapat dimintai pertanggung jawaban sesuai dengan teori accountability disamping responsibility yang berarti terdapat liability untuk tindakan Negara yang melanggar hukum internasional dan harus dilaksanakan. Negara memiliki keinginan untuk melaksanakan perbuatan atau mental capacity perbuatannya.

b. Tanggung jawab dan kewajiban suatu negara untuk melindungi warga negaranya yang berada di luar negeri diemban oleh fungsi konsuler suatu negara. Fungsi Konsuler di atur dalam Pasal 5 Konvensi Wina 1963 tentang Hubungan Konsuler. Penulis berpendapat Perwakilan Indonesia di Suriah telah berupaya melindungi dan memulangkan
WNI di Suriah, yang sulit adalah implikasi yang lahir dari ideologi yang timbul dalam konflik Suriah berupa paham radikal dan ekstrimis.

\section{Saran}

a. ICC berperan dalam menegakan hokum internasional bagi pelaku kejahatan perang di Suriah,ICC akan memiliki yurisdiksi jika seorang penjahat diduga memiliki kewarganegaraan dari anggota ICC, misalnya dual SuriahPerancis nasional di pemerintah yang terlibat dalam serangan. Ini akan menjadi tugas dari negara anggota yang relevan untuk membawa penuntutan.ICC bisa memiliki yurisdiksi jika korban serangan memiliki kewarganegaraan dari anggota ICC.

c. Maraknya peristiwa pelanggaran hukum yang menimpa warga negara Indonesia yang berada di luar negeri baik yang bekerja maupun menjalankan kegiatan 
Satria Nugraha, Tanggung Jawab Negara Dalam Penerapan Hukum Humaniter Internasional Studi Kasus...

lainnya menjadi peringatan

keras bagi Pemerintah

Indonesia untuk lebih

memperhatikan perlindungan

warga negara Indonesia yang

berada di Luar Negeri. Dalam

tulisan kali ini, penulis akan

menganalisis mengenai

Perlindungan Diplomatik

suatu Negara terhadap Warga

Negaranya yang Berada di

Luar Negeri Berdasarkan

Hukum Internasional

\section{DAFTAR PUSTAKA}

(Abu Faris. Analisis Aktual

Perang Badar dan Uhud

di Bawah Naungan

Sirah Nabawiyah.:

Rabbani Press. Jakarta, 1998

Andre de Hoogh, Obligations

Erga Omnes and

International Crimes,

Kluwer Law, The

Hague/London, Boston,

Andre Nollkaemper \& Dov Jacobs, Shared
Responsibility in

International Law: A

Conceptual Framework,

34 Mich.J. Int'lL. (2013).

Anthony Aust, Handbook of International Law,

Cambridge University

Press, 2007,

Anthony P.V.Rogers,

diterjemahkan oleh PLT

Sihombing dkk,

Bertempur secara Benar,

International Committee

of The Red Cross, jakarta, 2001.

Ambarwati., Hukum

Humaniter Internasional

dalam studi Hubungan

Internasional, Rajawali

Pers., 2009.

Arie Siswanto, Yurisdiksi Material Mahkamah Kejahatan Internasional, Ghalia Indonesia, Bogor, 2005 , 
Satria Nugraha, Tanggung Jawab Negara Dalam Penerapan Hukum Humaniter Internasional Studi Kasus...

Arlina Permatasari, Pengantar

Hukum Humaniter,

ICRC, Jakarta, 1999

Azzam, Abdullah.Al-aqidah

wa Atsaruha Fii , Binaa: Gema Insani

Press. Jakarta , 1994.

Edward k, Kwakwa, The

International Law of

Armed Conflict, Personal and Material Field of Application , Kluwer

Academic Publisher,

London, 1991.

Frederic De Mulinen,

Handbook on the Law of the War for Armed Forces, ICRC, Geneva, 1987,

Fournin, Henry, Komite Internasional Palang Merah Internasional dalam Hukum

Humaniter suatu

Persfektif, Pusat Studi

Hukum Humaniter \&
HAM, FH Trisakti,

Jakarta, 2003

Frits Kalshoven, Constraint on the Waging of War, ICRC, 1991,

Geza Herzegh, Recent Problem of International Humanitarian Law, ICRC, Budapest, 1981.

Haryomataram, Sekelumit tentang Hukum

Humaniter, Sebelas Maret University Press, Surakarta, 1994.

Huala Adolf, Aspek-Aspek Negara Dalam Hukum Internasional, Raja Grafindo Persada, Jakarta, 2002,

Higgins, Rosalyn, 1994, "Problem and Process: International Law and How We Use It", Oxford University Press, UK., 
Satria Nugraha, Tanggung Jawab Negara Dalam Penerapan Hukum Humaniter Internasional Studi Kasus...

Ida Bagus Wyasa Putra,

Tanggungjawab Negara

terhadap dampak

Komersial Ruang

Angkasa, Jakarta. Refika

Aditama, 2005

Iskandarsyah, Pengantar

Hukum Humaniter,

ICRC (International

Committee of Red

Cross), . Gramedia

Pustaka Utama, Cetakan

Kelima, 1999

Hukum

Humaniter, Rajawali

Press, Jakarta, 1994, hlm

63

J.G Starke, Pengantar Hukum

Internasional, Edisi

Kesepuluh, Jilid 1, Sinar

Grafika, Jakarta, 1997.

Jean Pictet . The principles of international

humanitarian law.

International Review of

the Red Cross, 1996,
Johan Galtung, Peace by Peaceful Means: Peace and Conflict, Development and Civilisation, Oslo, Prio

John E. Noyes \& Brian D. Smith, State Responsibility and the Principle of Joint and Several Liability, 13 YALE J. INT'L L. 225, 225 (1988).

KGPH Haryomataram, Pengantar Hukum Humaniter, RajaGrafindo Persada, Jakarta, 2005

L.C.Green, The Contemporary Law of Armed Conflict, Manchester University Press, New York, 1998.

Masjur Effendi, Moh. Ridwan, Muslich Subandi, Pengantar dan Dasar-dasar Hukum Internasional, IKIP Malang, Malang, 1995. 
Satria Nugraha, Tanggung Jawab Negara Dalam Penerapan Hukum Humaniter Internasional Studi Kasus...

Mc. Coubrey, Hilaire., International

humanitarian Law : the

Regulation of Armed

Conflicts,

Dartmouth Publishing Co.

Ltd, 1994

M. Aqastya ABM, Arab Spring:Badai Revolusi

Timur Tengah yang

Penuh Darah, Jogjakarta,

IRCisoD, 2014,

M. H. Hassan, Teroris

Membajak

Islam, Grafindo

Khazanah Ilmu, Jakarta, 2007.

M. Tahrir Azhary. Politik Internasional untuk Analisis, Jakarta, Grafika

Persada, 1993.

M. Tasrief, Hukum

Diplomatik (Teori dan

Prakteknya), Al-Ikhlas,

Surabaya, 1988

Mochtar Kusumaatmadja, Pengantar

Hukum
Internasional, Buku 1,

Cetakan Ketujuh, Bina

Cipta, Bandung, 1998

Hukum Internasional

Humaniter dalam

Pelaksanaan dan

Penerapannya di

Indonesia, Alumni,

Bandung 1980,s

Patricia W. Birnie, Alan e.

Boyle,1992, International

Law \& The

Environment, Oxford

Pietro Verri, The International law of Armed Conflict, ICRC, Geneva, 1992.

PLT Sihombing dkk, Bertempur Secara Benar, International Committee of The Red Cross, jakarta, 2001

Robert Kolb and Richard Hyde, An Introduction to the International Law of Armed Conflict, Hart 
Satria Nugraha, Tanggung Jawab Negara Dalam Penerapan Hukum Humaniter Internasional Studi Kasus...

Publishing, Oxford,

Portland Oregon, 2008.

Romli

Pengantar

Atmasasmita,

Pidana Internasional,

Refika Aditama,

Bandung, 2000.

Roy Gutman dan David Rieff,

Categories of War

Crimes, dalam Crimes of

War, WW Norton

Company, London,

Sandra Szurek, Responsabilitd de Pmtdger:

Naturedel'Obligation et

Responsabilite

Internationale, in socilt9

franaise pour le droit inter-national, colloque de nanterre: la responsabilitt de prot9ger 91, 100 (2008)

Sayidiman Suryohadiprojo, Si

Vis Pacem Para Bellum,

Gramedia Pustaka

Utama, Jakarta, 2005
Subakti, Ramlan. Memahami Ilmu Politik. Gramedia, Jakarta, 1992.

Sugeng Istanto, Intisari Hukum Humaniter Internasional, Palang Merah Indonesia, Yoygyakarta, 1990,

Hukum

Internasional,

Universitas Atmajaya, Yogyakarta, 1994.

Trias Kuncahyono, 2012, Musim Semi Suriah, Penerbit Buku Kompas, Jakarta,

Thontowi Jawahir dan Iskansar Pranoto, Hukum Internasional

Kontemporer, PT. Refika Aditama, Bandung, 2006

T. May Rudy. Studi Strategi Dalam Transformasi Sistem Internasional Pasca Perang Dingin. 
Satria Nugraha, Tanggung Jawab Negara Dalam Penerapan Hukum Humaniter Internasional Studi Kasus...

PT. Refika

Aditama.Bandung, 2003

Touvel, Saadi dan I. William Zartman. . International

Mediation in the Post

Cold War Eradalam

Chester A. Crocker, ad,

Turbulen Peace The

Challenges of

International Conflict.:

United State Institute of

Peace Press.Washington

D.C. 2001
Yoram Dinstein, The Conduct of Hostilities under the Law of Armed Conflict, Cambridge University Press, Cambridge, 2004,

Yustina Trihoni Nalesti Dewi, Kejahatan Perang dalam Hukum Internasional dan Hukum Nasional. Raja Grafindo, Jakarta, 2013〉

Christensen, Larry. B., 2004. Experimental

Methodology. $\quad 9^{\text {th }}$ edition.USA : Pearson Education Inc. 